\title{
The Development of Integrated Marketing Communications at the British General Post Office, 1931-39
}

In the 1930s, the General Post Office (GPO) in Great Britain became one of the nation's most innovative pioneers of marketing communication. Following criticism of the organisation in the 1920s for its conservative use of publicity, the GPO embarked upon a series of creative publicity campaigns that applied, amongst other methods, advertising, public relations, promotions, cinema, events and artistic posters. Through an overview of its publicity, and through a narrative of three case-studies, this article argues that one of the most important innovations of the GPO was its integration of its marketing communication, both in terms of its techniques and in relation to its emphasis on promoting both the organisation and its services. Whilst it has been argued that integrated marketing communication was not developed until the 1980s, this article argues that it can be detected in the GPO in the 1930s.

In the interwar period, the GPO in Britain was the country's largest organisation and employer. In the 1930s, it employed over 280,000 workers. ${ }^{1}$ The Post Office was in fact several businesses. Its primary activity was communication, including postal services, telegraphs and telephone. In addition, the GPO operated the Post Office Savings Bank, and oversaw the broadcasting license for the British Broadcasting Corporation (BBC), which it represented in Parliament. Finally, the GPO was responsible for the payment of government benefits, including old age pensions. With the increase in social welfare from the liberal reforms of 1906-14 onwards, the Post Office for many became the embodiment of the state. It was the one government institution that most people regularly interacted with. It is no surprise, for example, that during the Easter Uprising in 1916 in Dublin, the Irish republican forces occupied the GPO building and used it as their headquarters. This occupation was as much symbolic as it was strategic. $^{2}$

The interwar period witnessed a period of change at the GPO. It motorised its transport and began to develop both telephony and airmail. ${ }^{3}$ It was widely criticised, however, by business, politicians and newspapers for its failure to develop the telephone. In the 1920s the United States, Scandinavia and Germany had higher telephone penetration rates than Britain. This was felt to be both economically disadvantageous and a national disgrace. The GPO was held responsible, and was accused of being conservative and bureaucratic. Its failure to adopt modern marketing practices was seen to be a cause of this. The GPO did not advertise the telephone and was reticent to adopt other forms of publicity. It was only as a result of several official public enquiries in the 1920s and early 1930s, and of press campaigns engineered by business and individual politicians that this changed. ${ }^{4}$ In June 1931, a Telephone Publicity Committee (TPC) was established to oversee advertising and publicity. It was also allocated $£ 50,000$ by the Treasury. ${ }^{5}$ In July 1933 the Committee became responsible for all services in 
the GPO and renamed itself the Post Office Publicity Committee (PPC). ${ }^{6}$ In September of the same year, the old defunct publicity department of the GPO was transformed into the Public Relations Department under the pioneering leadership of the senior civil servant Sir Stephen Tallents. $^{7}$

The Public Relations Department at the GPO was one of the first to be formally established in Britain and alongside the TPC and PPC was responsible for some of the most innovative work in PR and marketing communications in the 1930s in Britain. ${ }^{8}$ Tallents himself would go on to set up the PR department at the British Broadcasting Corporation in 1935 and play a leading role in the establishment of the British Chartered Institute of Public Relations in 1948. ${ }^{9}$ It can be argued that the work that was carried out at the GPO in the 1930s contributed to the growth of public relations, corporate communications and integrated marketing communications (IMC) in Great Britain. It was at the GPO for example, that a clear distinction was made between selling advertising and prestige advertising, the latter referring to corporate communication and institutional promotion, what today we might term corporate branding. ${ }^{10}$ The GPO carried out market research, identified target markets, delineated, interacted and communicated with key stakeholders, planned communication campaigns and developed a highly innovative system of corporate communications, publicity, advertising and marketing for a growing range of products and services. ${ }^{11}$

Whilst publicity at the GPO has received attention, academic discussion has focused on the aesthetic and cultural merits of its communication rather than its proclivity to marketing, commercial orientation or organisational goals. ${ }^{12}$ Much of this has revolved around the documentary films that the GPO, under the direction of the GPO Film Unit, made in the 1930s. Initially discussion was dominated by film historians, while recently attention has focused on the role of the GPO Film Unit in forging British national identity in the 1930s. ${ }^{13}$ While not denying the artistic and social achievement of the Post Office's publicity, it must not be forgotten that these were means rather than ends. Commercial success and organisational reputation were always the main driving forces behind the publicity of the GPO in the interwar period. In emphasising this, one is reminded of Fine and Leopold's dictum that, 'advertising is itself concerned with the creation of a product ... and sold to make a profit.' ${ }^{14}$ This article adopts the latter perspective. It will argue that in the 1930s the GPO developed a highly complex form of marketing communication, which was innovative not only in the tools and mediums of its communication, but also in the way it integrated them. Applying the IMC model from marketing, it will demonstrate that the GPO was one of the first organisations to apply its principles to its communication. It did this by utilising multiple communication tools such as advertising, public relations and direct marketing in conjunction with several communication channels such as film, posters, print media and letter shots. This article will first provide a brief discussion and historiography of IMC. It will then examine the various communication tools and channels which the GPO utilised, and then proceed to demonstrate how the GPO applied IMC principles in its marketing communication through three case studies focusing on its Telephone Week campaign in 1934, the inauguration of the Anglo-Japanese international telephone service in 1935 and the launch of the Empire Air Mail Scheme in 1937. It will also discuss whether the adoption of an IMC approach to communication was intentional or 
operated on a more tacit level, and will conclude by arguing that an examination of the GPO during the 1930s provides historians with one of the first examples of the practice of IMC in the United Kingdom.

\section{Integrated Marketing Communication}

IMC is both a concept and a technique that is now prevalent in marketing communications, and has been adopted in the academic and professional fields of marketing. It is based on the idea that the several different tools of marketing communication - advertising, public relations, direct marketing, personal selling and sales promotion - should be integrated during communication campaigns to create clear and consistent messages, and to achieve synergistic benefits. It is seen as superior to traditional forms of marketing communication, in which the communication tools operate separately. For example, a public relations campaign using press editorials in newspapers could be integrated with advertisements that supported direct marketing and personal sales via the reader being able to send off for more information through a detachable part of the advertisement. In so doing, companies are able to maximise communications efforts towards targeted stakeholders and consumers. ${ }^{15}$

In addition, IMC is integrated in that it can affect not only cognitive but also behavioural and attitudinal change in consumers, whose aim is to ultimately result in purchase of a product or service. This is done by using marketing hierarchy of effects models such as AIDA (Attention, Interest, Desire and Action) or the Buyer Readiness Stage, and to co-ordinate these with IMC. ${ }^{16}$ In relation to the Buyer Readiness Stage, for example, customers are said to pass through several stages before buying a product. These are awareness, knowledge, liking, preference, conviction and purchase. IMC is argued to guide consumers through each of these stages by a strategic and coordinated use of communication tools. For example, a campaign to launch a new product may begin with a PR campaign to create awareness and then proceed to a mass advertising campaign to reinforce this. It could then switch to PR and personal sales to divulge knowledge of the product, before focusing on advertising and direct marketing to create an emotional bond amongst consumers. Finally, personal sales and promotion could be used to encourage conviction and purchase. IMC is thus not only tactical in its execution of communication, but also strategic in terms of its planning of communication campaigns. In this respect, the coordinated use of communication channels is as important as decisions involving tools. For example, in the above, hypothetical campaign, posters and print advertising could be used to create awareness, while television advertisements, using humour or celebrities would be more efficacious in affecting emotional responses.

The academic and professional literature for IMC is relatively new. The first definition for IMC was not given until 1989 by the American Association of Advertising Agencies, who stated that it was,

[a] concept of marketing communications planning that recognizes the added value of a comprehensive plan that evaluates the strategic roles of a variety of communication disciplines - general advertising, direct response, sales promotion, and public relations 
- and combines these disciplines to provide clarity, consistency, and maximum communication impact. ${ }^{17}$

The first academic piece of writing on the topic by Don Shultz did not appear until 1991. ${ }^{18}$ The first academic study on IMC appeared in the same year by Clarke Caywood, Don Schultz and Paul Wang. ${ }^{19}$ Uptake, however, was rapid. Clarke Caywood produced a monograph of IBM's use of IMC in 1992. ${ }^{20}$ By 1997 the subject had become an established part of marketing textbooks on marketing communications. ${ }^{21}$ It has subsequently enjoyed wide coverage and adoption in both academic literature and professional practice, and has effortlessly slid into the new era of digital marketing communications. ${ }^{22}$ In addition, our understanding of IMC has become more nuanced. Tom Duncan and Clarke Caywood in 1996 provided a model which outlined the different levels of IMC practice within the marketing communication activities of organisations. ${ }^{23}$ This had seven stages, which ranged from awareness, image, functional and co-ordination to more complex levels which integrated market research, stakeholders and the organisation as a whole. Finally, the topic has been insufficiently discussed within the field of business history. While Mariel Grant's work on the development of propaganda by the state in interwar Britain has paid some attention to the integration of press editorial and advertising, other work in the history of public relations and the growing field of marketing history in the United Kingdom has not addressed the subject. ${ }^{24}$ There has also been a lack of research on IMC in the United States in business history though Roland Marchand's and William Bird Jr.'s work on the development of public relations in American corporations in the first half of the twentieth century did note the integration of public relations with advertising. ${ }^{25}$

\section{Publicity and Marketing Communication at the GPO in the 1930s}

Whilst the GPO was criticised in the 1920s and early 1930s for its failure to adopt modern promotional practices, it would be unfair to say that it did not engage in marketing and publicity activities. When the TPC first met in July 1931 the GPO had developed a range of marketing communication tools and channels. In 1931, the GPO had a sales force of seven hundred contract officers, who sold telephones to the public through door to door canvassing and personal selling. This was supported by sales leaflets and pamphlets. These were distributed by targeted mail shots, through post offices, and were enclosed in telephone bills sent to customers. In addition, the GPO targeted professions such as doctors with leaflets and American tourists at hotels in London during the tourist season. Telephone leaflets often contained detachable sections that could be filled-out and sent to the Post Office requesting additional information. This was then directed to the sales team, which enabled them to follow up these requests and focus their activities. ${ }^{26}$ In addition, the GPO sent information and press releases to newspapers, which provided publicity for the corporation and its services. Most of this material was, however, factual and informative. 'Puffery', what today is commonly referred to as 'spin', and the boosting of sales though press editorial was officially eschewed by the GPO as a result of political pressure and adverse public opinion. ${ }^{27}$ In addition, the GPO took part in trade exhibitions and used posters to promote services. Both of these were limited by policies that prevented the Post Office from paying for space at exhibitions, from poor design, and from anodyne posters. In relation to the latter, the GPO had limited use of its own 
post offices to display posters, whose wall space was rented out to private advertising concerns and commercial companies. ${ }^{28}$

In addition to the GPO, the Telephone Development Association (TDA) also actively promoted and publicized the telephone. The TDA was established in 1924 by the leading manufacturers of telephones and telephone equipment in the United Kingdom as a result of the perceived failure of the GPO to commercially promote and sell telephone services. The TDA advertised the telephone in leading national and local newspapers, took part in industrial and trade exhibitions, provided lectures on the telephone to chambers of commerce and rotary clubs, and also provided telephone demonstration sets to schools. Much of this was done in co-operation with the GPO, with whom the TDA had an uneasy working relationship. TDA advertisements, for example, often contained an invitation for a free promotional booklet entitled, "Why aren't you on the telephone?" This booklet had a detachable postcard at the end that could be filled in and sent to the local post office contract office, which would direct leaflets and salesmen to the interested party. In addition, the TDA provided space to the GPO at exhibitions free of charge, received help from the Post Office in its work in schools, and also in 1931 began a joint poster advertising campaign on billboards. ${ }^{29}$

By 1931, the GPO and the TDA were thus utilising a range of marketing communication tools and channels to promote and sell the telephone. These were not, however, fully integrated, and nor were they being used to their full potential. This was reflected in the criticism of the advertising and marketing activities of the GPO, and its failure to promote the telephone in the United Kingdom. This changed in June 1931 with the creation of the TPC and in 1933 with the development of the public relations department at the GPO. The TPC was chaired by the Postmaster General and consisted of internal sales and publicity directors such as A.G. Highet from the sales department, H.E. Powell Jones from the TDA, and a number of high profile experts from the world of commerce and marketing. This included Sir William Crawford, one of the most important figures in interwar marketing in Britain and a pioneer of the application of modern art to advertising, Sir Francis Goodenough, controller of the Gas Light and Coke Company and a leading authority on salesmanship, and Sir Stephen Tallents, a central figure in the development of public relations in the United Kingdom. ${ }^{30}$ Other prominent businessmen joined the renamed PPC in 1933. These included John Grierson, the founder of the documentary film movement in Britain, Lord Iliffe, the newspaper proprietor and A.P. Ryan and Jack Beddington who were publicity directors at the Gas, Light and Coke Company and Shell-Mex respectively. ${ }^{31}$ The latter was particularly prominent in his role in the development of poster publicity. ${ }^{32}$ In 1936, E. Rawdon Smith, the public relations officer, of the London Transport Board (LTB), joined the PPC. This institution, under Francis Pick, had been a pioneer in the development of public relations through art, architecture and design. ${ }^{33}$ These individuals were instrumental in the development of IMC at the GPO, particularly in its application of modern art, in introducing a range of communication tools and channels, which included public relations, event management and film, and in the integration of these communications devices. In so doing these figures transferred marketing techniques and strategies which they had developed at their own companies, such as Crawford's advertising 
agency, the LTB, the Gas Light and Coke Company, Shell-Mex and the Empire Marketing Board (EMB).

The last of these organisations was central to the rejuvenation of marketing communication at the GPO. The EMB was a quasi-government body, whose role was to promote trade within the British Empire. ${ }^{34}$ It was created in 1926, partially as a fillip to those who had failed to establish tariffs and imperial preference (free trade) within the Empire, and came to an end in 1933 when these were established in the wake of the 1930s slump. The EMB was active in scientific research aimed at assisting intra-empire trade, and in the development of publicity to promote this trade. It was particularly noted for its innovative marketing techniques including its posters, films on empire topics, exhibitions and events, such as "Empire Shopping Week", its Empire shops, lectures and radio talks, its work in schools and its use of press editorial. ${ }^{35}$ Many of the members of the TPC and PPC, such as Crawford, Grierson and Tallents came from the EMB, and with its demise, many of its marketing resources, such as its film unit and its expertise in poster and exhibition production, were transferred to the GPO. ${ }^{36}$ Amongst these, Tallents was particularly instrumental. He joined the TPC at the outset in 1931 and was made the Public Relations Officer of the GPO in September 1933. Tallents played an important role in the transferral of the marketing assets of the EMB to the GPO, in the integration of the GPO's marketing communication and in the rejuvenation of its corporate brand.

A pivotal change that the TPC brought to the marketing of the GPO was its emphasis on developing 'telephone mindedness' in Britain. While the earlier marketing of the GPO had focused on selling the telephone, it was argued that it had neglected to educate the public about its benefits or to create a need for its services. An early report on its publicity activities noted,

It may be said that the shortcomings of the present method of telephone publicity are that in the main they aim at selling telephone services to the individual without first creating a sense of need among the public generally. In other words there is little mass suggestion. Whilst therefore existing methods, could doubtless be extended and improved upon, future publicity developments should first of all be in the direction of awakening a national 'telephone-mindedness' and obtaining the good will of the public. $^{37}$

This was done in a number of ways. The GPO developed national telephone campaigns such as its 'Come On the Phone' campaign of 1933-34 and its national 'Telephone Week' in 1934. ${ }^{38}$ Through its films, press advertising, exhibitions, editorial and work in schools it reached millions of people. ${ }^{39}$ The telephone became a phenomenon that saturated the media and became a norm in people's everyday lives, rather than a gimmick or a luxury for the rich. Furthermore, via its communication it associated the phone with modernity, technology, art, culture and the home. This induced powerful emotional and symbolic appeals that had been lacking in previous publicity. ${ }^{40}$ Finally, the GPO began to apply prestige advertising. A key strategy in its marketing communication in the 1930s was the development of a distinct corporate identity and brand for the GPO, which had synergistic benefits for its services. This was done by creating messages and associations of public service, science, national identity and empire. ${ }^{41}$ Through its services of communication, powered by its research and technology, the GPO 
claimed that it integrated the nation and empire into a stronger whole. This can be seen, for example, in its poster campaigns, 'Outposts of Britain' and 'Outposts of Empire', in its films such as 'Night Mail' (See Figure 1) and 'Calendar of the Year', and in its communication campaigns for airmail that were immersed in imperial symbolism. ${ }^{42}$

Figure 1 Night Mail Poster designed by Pat Keely, 1936. (C) Royal Mail Group Ltd 2011. Courtesy of The British Postal Museum and Archive

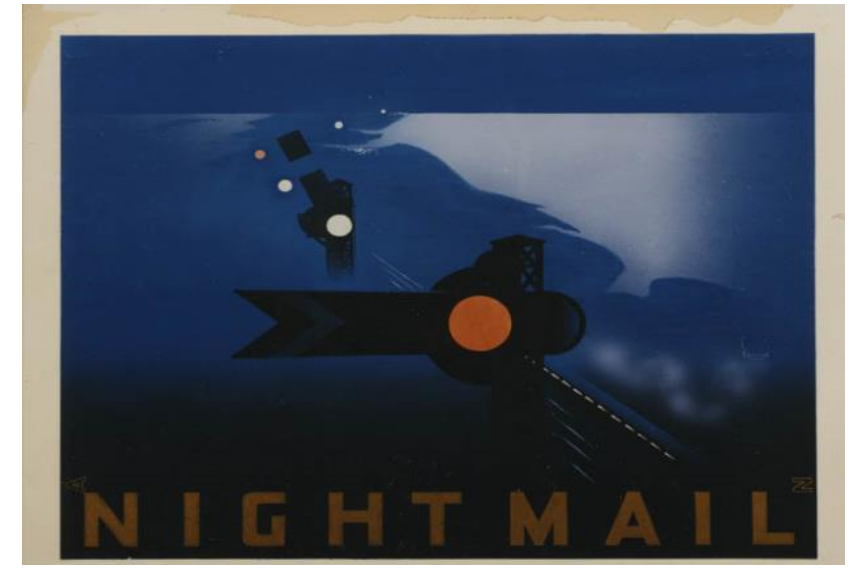

Source: RMA POST 109/377.

In 1934, Tallents published an article entitled 'Post Office Publicity' in the internal Post Office publication, Green Papers. ${ }^{43}$ The paper carefully listed the roles and purpose of publicity at the GPO. On the one hand, publicity acted at the Post Office in the same way it did at other commercial companies. It was furnished to promote products, build up brand awareness and knowledge, create needs and maintain customer loyalty. ${ }^{44}$ Yet on the other hand, as a major public institution, publicity was aimed at fulfilling several distinct roles. As an organisation which sold a public good - communication - the Post Office was accountable to society. The GPO used publicity to provide information about its services to the general public. Through its communication, it explained and demonstrated how the Post Office functioned. In this respect, it had an educational and informational purpose. ${ }^{45}$ PR was also used to create links with important stakeholders, such as chambers of commerce, politicians, education authorities, the press, the BBC and local communities. It was also used to induce co-operation from the public. The efforts of the GPO to encourage people to post early so as to distribute the delivery of mail over the day is a case in point. ${ }^{46}$ Finally, the GPO had a much grander aspiration of representing the nation to itself, of providing it with a sense of identity and meaning. As Tallents wrote, 'We need to build up, piece by piece, a picture of our own people, and also for others, of what this country has done, is doing and seeks to do in its endeavour to equip itself ... to meet a wholly new range of modern conditions. ${ }^{47}$ Press advertising, posters, exhibitions, post office shops, films, press and newsreel editorials, speeches, lectures, broadcast addresses, publicity literature, event management, and relations with representation bodies were combined to realise these commercial and public goals. ${ }^{48}$ 


\section{Telephone Week}

On October $1^{\text {st }}, 1934$ Telephone Week was launched by the GPO. This was the most extensive marketing campaign to promote the telephone in Britain in the 1930s, and serves as an excellent example of the use of IMC by the TPC/PPC and the public relations department of the GPO. ${ }^{49}$ Telephone week was precipitated by a reduction in telephone charges across the country and the introduction of reduced rates for long distance phone calls between $7.00 \mathrm{pm}$ and $7.00 \mathrm{am}$. In addition, a new range of coloured hand microphone sets were introduced. Telephone Week was more, however, than simply a promotional exercise for a reduction in telephone charges. It was the culmination of the 'Come on the Phone' campaign of 1933-34 whose aim was not to simply sell more telephone services, but engineer an attitudinal change in Britain that the telephone was an item which was indispensable to modern living. ${ }^{50}$ It was an exercise in the creation of 'telephone-mindedness' across the nation.

During Telephone Week, the GPO utilised all of its communication tools and channels, which have been outlined above. ${ }^{51}$ The campaign began with press advertisements being placed in the national dailies and in fifty provincial newspapers. These contained coupons that could be filled in and sent to the GPO asking for more information about their telephone service (See Figure 4). The event was also launched by a press conference and a BBC radio broadcast by Sir Kingsley Wood, the Postmaster General, to announce the reduced rates and the beginning of the campaign. ${ }^{52}$ This was supported by a series of editorials and statements that were supplied to the press throughout the campaign, the reporting of the campaign by the news programme of the BBC, and the broadcasting of speeches by Sir Edward Campbell, the parliamentary secretary to Sir Kingsley Wood, at Birmingham and Edinburgh. ${ }^{53}$ In addition to advertisements, press and radio editorial, a number of posters were designed for the campaign by well-known artists, including, 'Come on the telephone' by McKnight Kauffer (see Figures 2 \& 3). These were shown on post vans, in exhibitions in post office shops, in post offices, in shop windows, and were exhibited by businesses which assisted the GPO during the campaign. Nearly 300,000 posters were exhibited and nearly 500,000 post cards, which reproduced the poster designs, were distributed. ${ }^{54}$ Special leaflets were designed and sent through telephone bills, salesmen and local post offices. In addition, over six millions adhesive labels were sent to business firms urging them to place their orders over the telephone. Six lectures were prepared for Telephone Week and were given to societies and civil associations across the country. ${ }^{55}$ Sales desks, or 'telephone bureaus', were established in post offices, where the new phones were displayed, information on the reduced charges provided and requests for visits by the sales made. ${ }^{56}$ Civic visits to telephone exchanges by local dignitaries were also arranged during Telephone Week and ceremonies involving telephone calls took place in major cities such as Leeds, Glasgow and Liverpool. In London, the cable ship 'Monarch' was used as an exhibition centre during telephone week and was visited by the Lord Mayor of London, politicians, the celebrity Gracie Fields and the general public. ${ }^{57}$ Film was also used by the GPO. This included newsreel reports on the visit of the Lord Mayor of London to the cable ship, the Monarch and a two minute trailer film entitled, 'Come on the Telephone', which was shown in cinemas across Britain. ${ }^{58}$ Finally, regional and local post offices were encouraged to develop their own 
promotions. For example, in Edinburgh and Glasgow, illuminated tramcars encouraged people to 'Get on the Telephone'. 59

Figure 2 Come On The Telephone Poster designed by Edward McKnight Kauffer, 1934. Courtesy of BT Heritage \& Archives

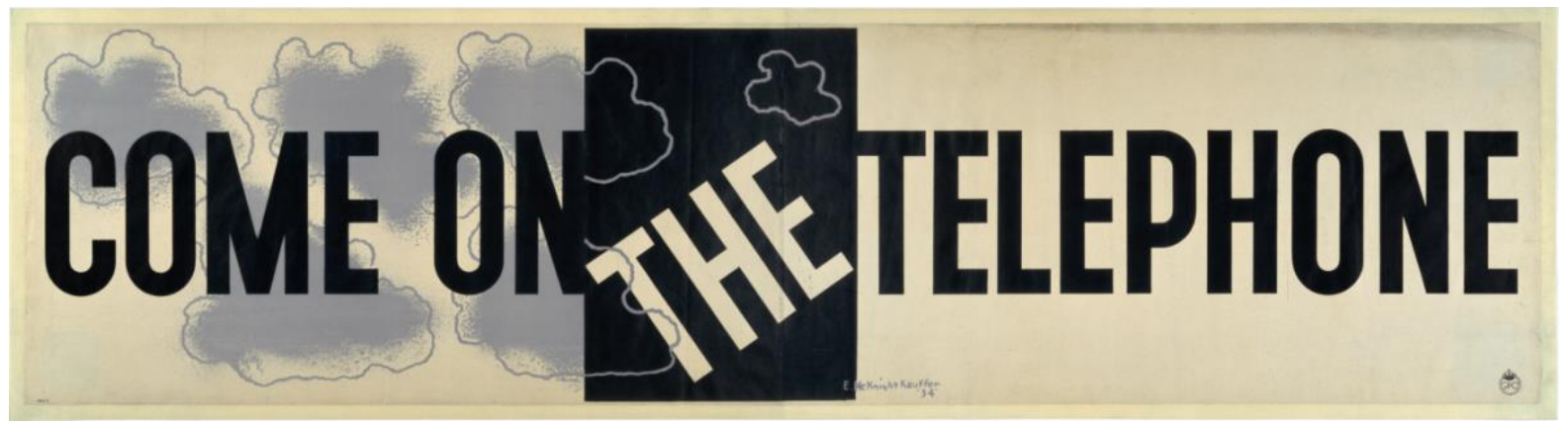

Source: BTA PRD 71.

Figure 3 Photo of GPO Van during Telephone Week, 1934 with Kauffer's Poster and Staff outside an Unidentified Local Post Office. Courtesy of BT Heritage \& Archives

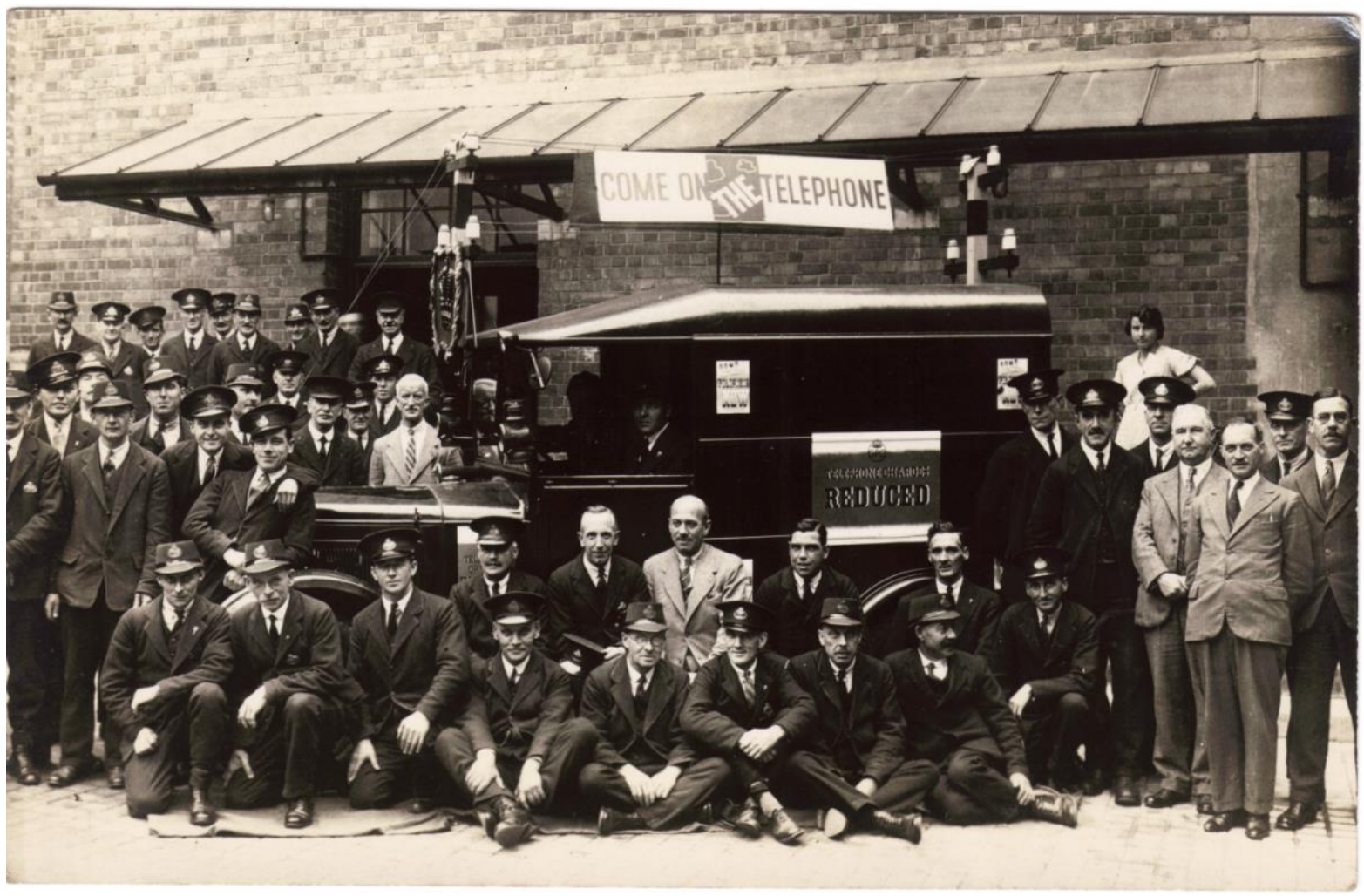

Source: BTA TCG 263/22.

Telephone Week utilised all of the tools of IMC. Advertising, public relations, personal selling, direct mail and promotion were all used. These tools were communicated across a range of channels that included the press, the radio, film, posters, leaflets, lectures, exhibitions and retail outlets. Yet what calibrated their communicative efficacy was the fact that they were integrated. Adverts in newspapers were supported by sales teams and public relations. News stories on 
Telephone Week, for example, which originated in press conferences and press releases, sat alongside telephone advertisements and coupon advertisements in national and local newspapers (see Figure 4). ${ }^{60}$ Events and ceremonies such as the visit of the Lord Mayor of London to the Monarch and civic dignitaries to telephone exchanges were broadcasted by newsreel companies and newspapers. ${ }^{61}$ Post office shops and sales bureaus in post offices were supported by exhibitions, posters, leaflets and sales teams. ${ }^{62}$ In addition, a number of key stakeholders were enlisted to assist the GPO during Telephone Week including businesses, politicians and civic dignitaries and societies such as chambers of commerce, rotary clubs and schools. ${ }^{63}$ The communication campaign followed a clear strategic path, which resembled the buyer readiness stage. It created awareness about the reduction in telephone charges, provided information and extolled individuals to adopt the telephone. Whilst emotional appeals were attenuated, they are evident in the use of films and posters and the use of civic dignitaries and celebrities such as Gracie Fields. Finally, Telephone Week not only attempted to sell telephone services, but also sought to provide legitimation and credibility to the telephone service and the GPO. As the head of the London Telephone Service commented at the end of the event, '...there is no doubt that the Campaign was a successful one, and, apart from the new business secured, has done much to foster that goodwill between the public and the Post Office which is so valuable an asset.' 64

Figure 4 Newspaper Article and GPO Coupon Advertisement in Daily Telegraph during Telephone Week, 1934 (C) The British Library Board. Courtesy of The British Library 


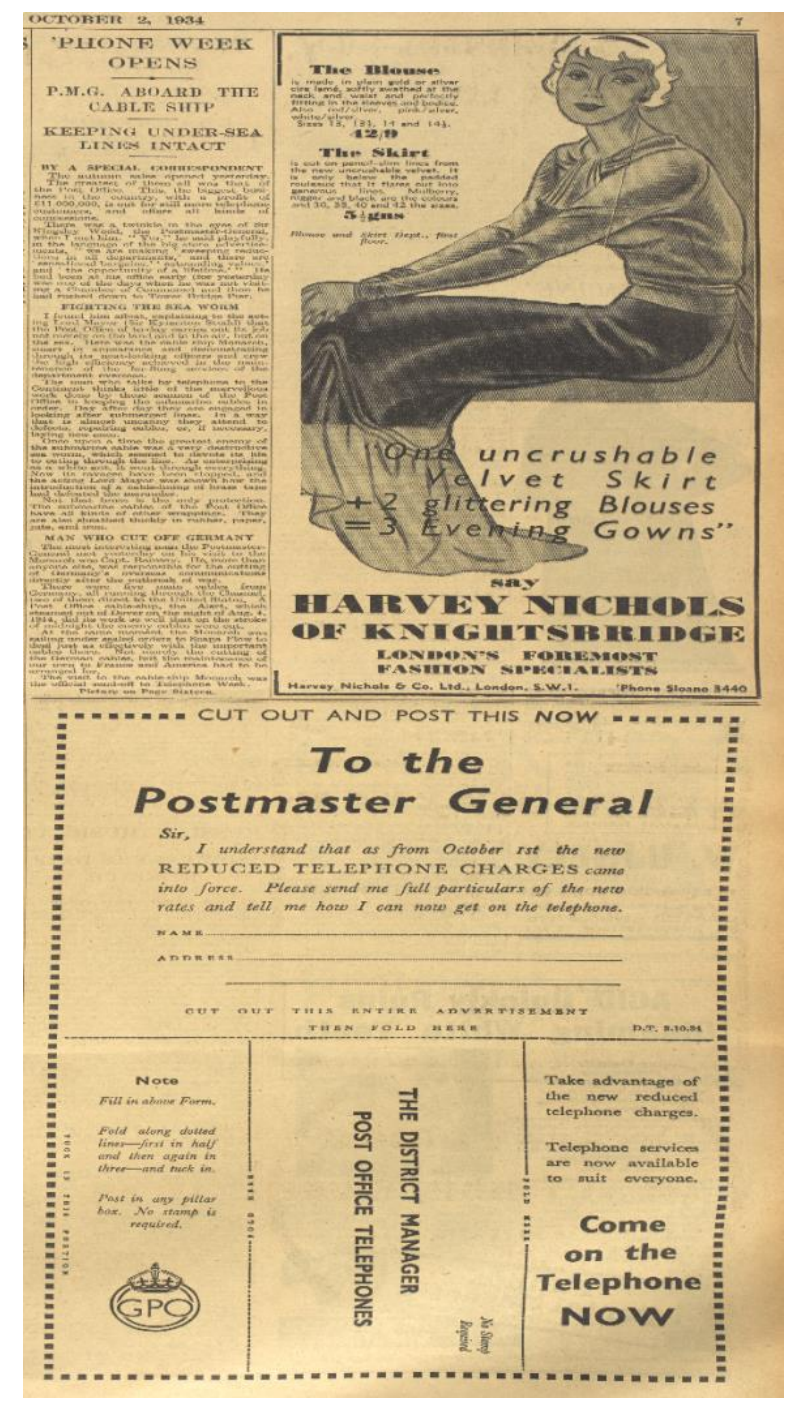

Source: Daily Telegraph, October 2, 1934, 7.

As the last quote suggests, the campaign was perceived at the GPO as being successful. The coupon advertising campaign in the newspapers, for example, produced 11,396 replies, which led to 2,908 exchange line orders and 971 miscellaneous orders. ${ }^{65}$ Telegraph reports from postmasters across Britain commented on the widespread public interest in the campaign. In London, orders were received for 926 lines and over 400 microphone telephones. Nearly 5000 press coupons were returned. Press editorial garnered 1,100 column inches and a large number of business firms and shops assisted in the campaign, including a special exhibition at Selfridges Department Store on Oxford Street. These assisted in displaying around 26,000 posters. In addition, lectures were given to 68 associations, including rotary clubs, chambers of commerce and literary clubs and 923 politicians, public figures, civic dignitaries and large business subscribers visited the Monarch Cable ship. Similar exhibitions and events at exchanges and post offices were popular and received strong attendances. The "Get on the Telephone" film clip was shown across 73 cinemas. Finally, reports from local post offices across London also attest to the success of the campaign, especially the popularity of the 
telephone bureaus. ${ }^{66}$ These were felt to be particularly effective in educating people about the new charges. Reports from other parts of the country such as Scotland also commented favourably on the campaign. ${ }^{67}$

\section{The Inauguration of the Anglo-Japanese Telephone Service}

At 9 am, 12 March 1935, the first telephone call was made between London, England and Tokyo, Japan. With this, the Anglo-Japanese telephone service officially began operating. ${ }^{68}$ By the mid-1930s the GPO had become one of the leading pioneers of international telephony. Using a mixture of land cables and radiotelephony, transmitted from its powerful radio station in Rugby, England, most of the world's telephones were accessible through its international telephone exchange at London. The latter was commonly referred to as the "switch board of the world'. ${ }^{69}$ Since its inauguration of telephone services to Australia in 1931 and India in 1933 the GPO had marked the opening of new international telephone lines by a ceremony in which public figures in respective countries spoke over the telephone with each other. The press and newsreel companies were invited. Reports of these events were subsequently reproduced in newspapers and cinemas across Britain and abroad, providing publicity for the new services and the GPO. ${ }^{70}$

The inauguration of the Anglo-Japanese telephone service was a highly elaborate telephone ceremony. In London, the Post Master General, the Foreign Secretary and the Japanese Ambassador rang up in Tokyo, the Japanese Minister of Communications, the Japanese Minister of Foreign Affairs and the British Ambassador. A number of other prominent individuals also took part including the President of the Federation of British Industries, the Chairman of the Japan-Great Britain Trade Council in Tokyo, and representatives from press agencies in both countries. ${ }^{71}$ The press and newsreel companies from British Movietone News, Pathe Gazette, Paramount News and Gaumont British were invited to the ceremony, which was also broadcast on national BBC radio. Copies of the film were also sent to Japan, the United States and the Continent. ${ }^{72}$ Support for the event from the press editorial unit of the public relations department at the GPO was particularly strong. Details of all the participants were sent to the British press, copies of speeches by the Japanese Minister of Communications, the British Postmaster General, the Japanese Minister of Foreign Affairs and the British Foreign Secretary were provided, and details of the new service were given, including a technical diagram showing how the new international telephone functioned. ${ }^{73}$

In terms of publicity, the inaugural ceremony created high levels of exposure. Over 2000 column inches were obtained in the press, which included leading articles and photographs. ${ }^{74}$ The story was carried in all the British national dailies, which reproduced to varying degrees material from the GPO press release. ${ }^{75}$ The news report from British Pathe newsreel, which reached millions of cinemagoers across the UK, was nearly two minutes long, and included extracts of speeches from Sir Kingsley Wood, the Postmaster General and the Japanese Ambassador, Yuri Sensei. ${ }^{76}$ Whilst the new service was prohibitively expensive, a three minute call to Japan costing six pounds, more than the weekly average wage of most Britons, the publicity and prestige value for the GPO, its corporate brand and its telephone service were high. The newsreel report, for example, emphasised the scientific achievement of the event and 
the clarity of the telephone call. ${ }^{77}$ The quality of the telephone call was also noted in newspaper reports, and many repeated Sir Kingsley Wood's comment in his speech that London was at the centre of the world international telephone system. ${ }^{78}$ Associations of modernity, technology and national pride for the GPO and its telephone service were, through third party endorsement, produced by public relations. Finally, a newspaper advert for the telephone was placed in the Daily Telegraph, which ran a full feature on the ceremony, thus integrating public relations with advertising. ${ }^{79}$ In the inauguration of the Anglo-Japanese Telephone Service we can observe the GPO utilising event management, press and cinema editorial, and advertising in its marketing communications.

\section{The Empire Air Mail Scheme}

The final case-study will examine the application of IMC to the inauguration of the Empire Air Mail Scheme in May/June 1937. A central development by the GPO in the interwar period was its inauguration of airmail. With an empire spanning a third of the world, the development of infrastructure for the distribution of post by air was clearly pertinent to the United Kingdom. The GPO, in collaboration with Imperial Airways and the British Air Ministry, focused heavily on the extension of this service in the 1930s, and devoted a great deal of energy and resources to its communication and promotion. The inauguration of the first airmail service to Australia, for example, in December 1934, was launched by an elaborate ceremony at Croydon Airport near London. The ceremony pivoted on the sending of the first airmail on the service by King George V to his son, the Duke of Gloucester, who was in Auckland, New Zealand. Present at the ceremony was the British Minister of Air, Lord Londonderry, the Post Master General and the chairman of Imperial Airways. Lord Londonderry handed the royal mail, contained in a blue silk bag, to the Postmaster General, who stamped it and then handed it to the chairman of Imperial Airways, who delivered it to the plane. Speeches were made to guests, and representatives of the press and newsreel companies were present. A message was also read by Mr S.M. Bruce, the High Commissioner for Australia. ${ }^{80}$

On 29 June 1937, the GPO, in conjunction with Imperial Airways, launched the Empire Airmail Scheme. This new service began the process of the sending of all mail within the British Empire by air. Previously this had been delivered by a mixture of sea, land and air. In addition, surcharges for airmail were abolished. All first class mail sent by air was now charged at a flat rate of $1 \frac{1 / 2}{2}$ pence a half ounce. The scheme offered a service that was cheaper, faster and more convenient. The development of the scheme was staggered into three phases. The first, launched in June 1937, began the operation of the England to South Africa airmail route. The second, the England-India-Burma-Malaya route was launched at the end of May, and the final England to Australia route started at the beginning of 1938. Empire Airmail was the largest international distribution system of post in the world at the time, involving in its first stage the co-operation of fifteen countries and a large number of airlines. It marked the beginning of affordable airmail, and was promoted as bringing the nations of the British Empire and Commonwealth closer together. ${ }^{81}$

As in the launch of the airmail service to Australia in 1934, a ceremony marked the launch of the new service. This took place on the steamship Medina, which was moored next to the 
Imperial Airways flying boat aeroplane Centurion that was bound for South Africa with 3,500 pounds of mail. The ceremony was almost identical to that described three years earlier for the inauguration of the Anglo-Australian airmail service. It too involved the delivery of airmail from the King, this time to the Governor-General of South Africa. The Minister of Air, Postmaster General and Chairman of Imperial Airways were present, as was the Minister of Posts and Telegraphs for South Africa. ${ }^{82}$ Members of the press and newsreel companies were invited and the speech of the Postmaster General was broadcast by the BBC. ${ }^{83}$ Following the ceremony, a luncheon was held at a hotel in Southampton where more speeches were given. Press releases for the ceremony, including details of the Empire Airmail Scheme and copies of speeches were sent to the press and the ceremony was given full coverage in all the major dailies. ${ }^{84}$ The integration of newspaper articles with advertisements for the new scheme in the same newspapers was also found. ${ }^{85}$ In addition, the GPO designed posters and cards for Empire Airmail, published leaflets and explanatory folders, and held a meeting on 27 May 1937 with representatives from the Federation of British Industries, the Association of British Chambers of Commerce and other major companies to explain the new imperial airmail system. Imperial Airways also organized a special exhibition train to publicise the new scheme, which toured the United Kingdom. ${ }^{86}$

Figure 5 GPO Advertisement for Empire Airmail Scheme in The Times, June, 1937 (C) The British Library Board. Courtesy of The British Library 


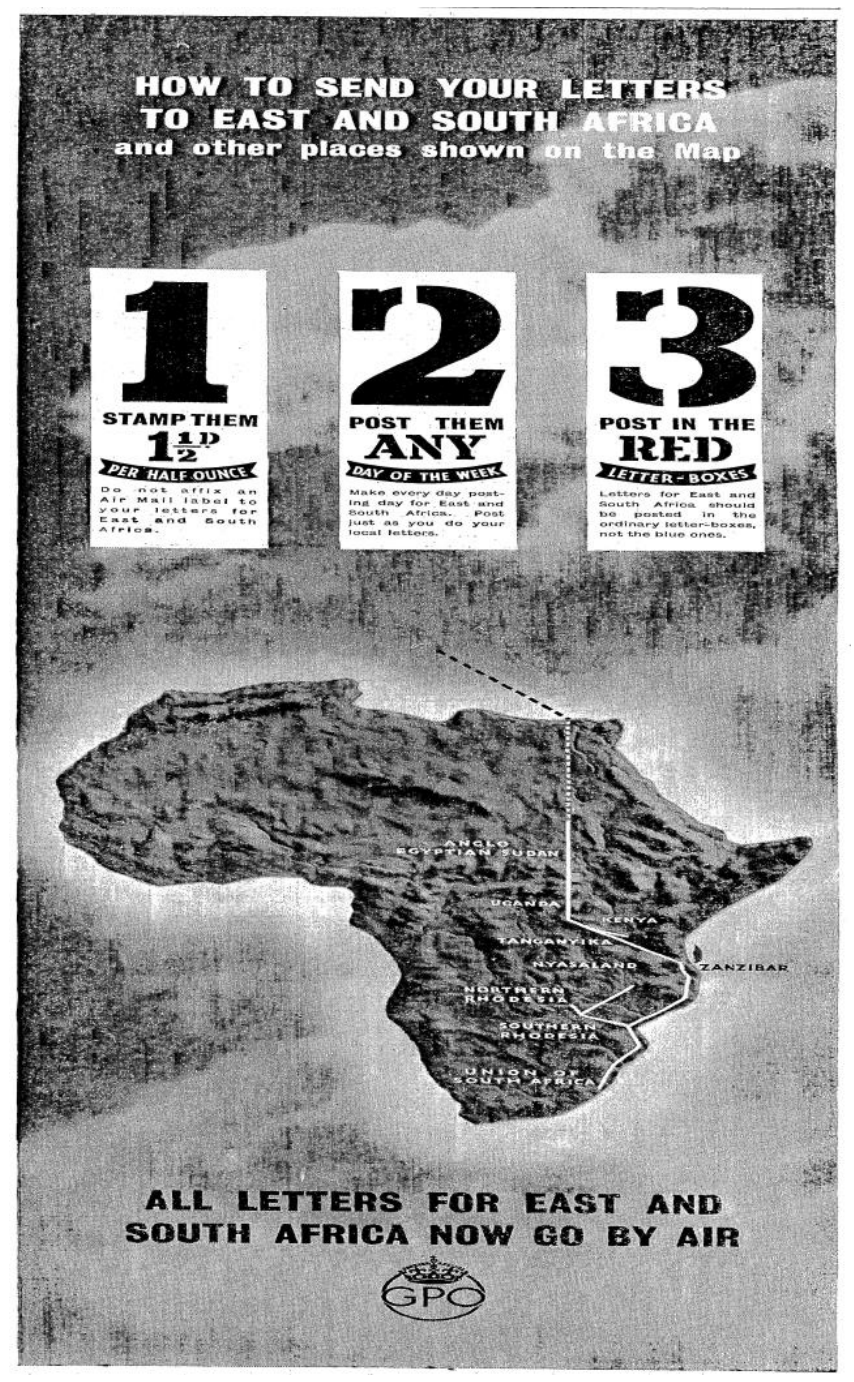

Source: The Times, June 30, 1937, 9.

It is interesting to note that a major aim of the GPO's communication campaign was not only to promote the new system of airmail, but also to attempt to change the public's posting behaviour. While the older system of imperial mail was based on one delivery a week, the new scheme was premised on three smaller weekly deliveries. In order for this to work individuals and companies had to be encouraged to spread their post over the week rather than concentrate on sending it over one or two days. If this took place, the system would not work as planes were not able to carry such heavy mail loads. As a PPC report stated,

The main point of the publicity appeal is to encourage users to spread their postings over the week instead of waiting as for a weekly mail-day. Another point is to get the public to customise themselves to the new postage rate. Further points to be brought out in the publicity are that there is no need to affix air-mail labels to letter and postcards going by the new service ... ${ }^{87}$

Speeches, press releases, posters, printed material and meetings with businesses all emphasised the above points. The advertising, publicity and public relations of the GPO's IMC during the Empire Airmail Scheme campaign focused not only on selling and embellishing the corporate 
brand of the Post Office, but also on educating its users so as to ensure a successful and smooth running service.

\section{Purposeful Action or Serendipity?}

Having examined the use of IMC at the GPO in the 1930s, one important question which remains to be asked is to what extent this was an intentional strategy of the Post Office? Did the GPO integrate its communication or did it simply use a battery of tools and channels without any concept of their worth as a combined whole? Examining the minutes of the TPC and the PPC it appears that there was an awareness of the synergistic benefits of combining different forms of communication. For example at a meeting of the TPC on 8 December 1931, during a debate over the merits of press publicity, Stephen Tallents stated that, "In his opinion editorial publicity was a cardinal necessity for the success of the advertising. ${ }^{88}$ At a meeting of the committee in July 1932, a discussion on the role of advertising took place. Sir William Crawford emphasised that the importance of advertising was not just in selling products, but also in increasing the prestige of the GPO. Individuals saw such advertisements as a sign of vitality of the institution. He also noted the positive effect it had on the sales staff, 'He was informed that the many inquiries made on this point [advertising] indicated that the campaign had helped the salesmen in their work and that it had created a consciousness in their own minds that they were part of a living organisation.' ${ }^{89}$ A meeting in July 1933 further noted that, 'advertising and publicity generally were having a snowball effect.' ${ }^{90}$ It was observed that advertising and press editorials were leading to newspapers and publishers increasingly asking for articles and information on telephones from the GPO, which they in turned published. Here is a clear acknowledgement of the synergistic effects of advertising and public relations through press editorials and third party endorsement. Whilst there were members of the publicity committees, such as Mr Powell Jones of the TDA, who argued that the GPO should simply focus on advertising to sell telephones, there was an overall consensus that the use of combined forms of publicity, and an emphasis on both selling and prestige advertising, was the most effective form of marketing communication.

\section{Conclusion}

On 6 May 1937, the Chairman of the PPC announced that the GPO was facing problems with keeping up with demand for its services. He stated that this was because,

the effects of recent reductions in rates and the accumulated effects of telephone publicity had been much in excess of expectation. The Post Office was at present going through a period in which it was experiencing some difficulty in keeping abreast of orders and in carrying out necessary renewals and extensions of exchange equipment. ${ }^{91}$

The result of this was a six-month moratorium on GPO publicity for the telephone, and a refocusing of communication to explain the delays and describe what the Post Office was doing to resolve them. The incident not only illustrates the success of the GPO in marketing the telephone in the 1930s, but also points to its strategy of reducing prices and an emphasis on marketing communication. A second strategy can be seen in the rebuilding of the organisational reputation of the GPO through an emphasis on corporate branding. This was fundamental to 
restoring institutional legitimacy and credibility. Without this the GPO could neither effectively sell its services nor have a license to operate. Similar to its strategy of price reduction, this was contingent on a successful application of marketing communication.

This strategy was highly successful. The United Kingdom rose up the international league table of telephone penetration. ${ }^{92}$ Telephone profits increased from breakeven in 1929-1930 to £2.1 million in 1934-35. ${ }^{93}$ By the latter half of the 1930s the GPO was adding 200,000 new telephone subscribers every year. ${ }^{94}$ Airmail traffic increased from 10.8 million tons in 1935-6 to 91.2 million tons in $1938-9 .{ }^{95}$ Similar growth occurred in telegraphs and the Post Office Savings Bank. ${ }^{96}$ In addition, there was a marked improvement in the corporate reputation of the GPO. The parliamentary estimates debate in the House of Commons in June 1934, commended the Post Office on improving its public image. The Postmaster General was praised for increasing its efficiency and sense of corporate pride. ${ }^{97}$ The Times joined in with this chorus of approval. In December 1934, it stated, 'During the last two years things have been as rapidly changed in the Post Office as they have been in any business house in the Kingdom, and changed with as clear an eye to progress and efficiency. ${ }^{98}$ Praise for the Post Office, according to the article, was now widespread.

Marketing communication was acknowledged as playing an important role in the success of the GPO. Yet this was not due simply to its extent, its content or its artistic merits. It was also a result of its integrated nature, which led to synergistic benefits in terms of its coverage, penetration, and impact amongst targeted audiences. The PR department of the GPO created events such as Telephone Week and inauguration ceremonies, which generated stories in the media. News reports, based on GPO press releases, reinforced advertisements placed in the same publications. Similarly, coupon advertisements were integrated into direct marketing programmes and sales teams. All of these were often linked to promotional campaigns which reduced prices for services. Publicity in terms of press, radio and newsreel coverage also undergirded the efforts of the telephone sales teams. There is also evidence of a direct link between press advertising by the GPO and the willingness of papers to accept press releases. During Telephone Week, for example, many provincial newspapers refused to assist the GPO in terms of press coverage due to a lack of advertising by the latter in their newspapers. ${ }^{99}$ It has also been shown that there was integration between corporate and product marketing communication at the GPO in the 1930s, with communication campaigns often designed to support both. Finally, the GPO's communication was integrated in terms of implementation. Public relations and advertising were often used at the beginning of campaigns to create awareness and knowledge, whilst sales teams and direct marketing were used later to garner consumption and purchase.

The above conclusions have implications for our attitudes towards the history of advertising and organisational communication. This article suggests that IMC is much older than its proponents in the 1980s and 1990s would have us believe. More research here is needed in order to ask whether the GPO was an isolated case or whether it was indicative of an emerging form of marketing communication. The fact that there were so many parties from other companies on its publicity advisory boards suggests that the latter may have been the case. Finally, this article indicates the highly advanced nature of marketing communications in 
Britain in the interwar period. ${ }^{100}$ Its combination of both public relations and advertising for publicity purposes is of particular importance both for business historians, who have tended to focus on advertising, and historians of public relations, who have focused overwhelmingly on the political and cultural. This case study of the GPO offers a new paradigm through which the history of commercial and organisational communication can be studied.

Notes 
${ }^{1}$ Campbell-Smith, Masters of the Post The Authorized History of the Royal Mail, 304.

${ }^{2}$ Ibid., 258-264.

${ }^{3}$ Ibid., 277; Anthony, "The GPO Film Unit and 'Britishness' in the 1930s," 10.

${ }^{4}$ Campbell-Smith, Masters of the Post, 264-272, 282-297; Grant, Propaganda and the Role of the State, 82-98.

${ }^{5}$ Ibid., 100-107; Royal Mail Archives (hereafter RMA). POST 108/5, 'Post Office Publicity Committee Minutes of Meetings 1931-33, June 25 1931'.

${ }^{6}$ Ibid., July 121933.

${ }^{7}$ Campbell-Smith, 304-314.

${ }^{8}$ Ibid., Grant, Propaganda, chapter 4; L’Etang, Public Relations in Britain.

${ }^{9}$ Anthony, Public Relations and the Making of Modern Britain.

${ }^{10}$ RMA POST 108/5, 'Post Office Publicity Committee Minutes of Meetings 1931-33, July 4 1932', 'Post

Office Committee Meetings 1936-37, June 8 1936'. See also Balmer, “Corporate marketing."

${ }^{11}$ RMA POST 108, 'Post Office Publicity Committee Minutes of Meetings 1931-139'; Grant, chapter 4;

Anthony, Public Relations and the Making of Modern Britain, chapter 2.

${ }^{12}$ Anthony and Mansell, The Projection of Britain.

${ }^{13}$ Ibid., "Introduction: The Documentary Film Movement."

${ }^{14}$ Church, "Advertising consumer goods."

${ }^{15}$ Duncan and Caywood, "The Concept, Process, and Evolution of Integrated Marketing Communication."

${ }^{16}$ Barry and Howard, "A Review and Critique of the Hierarchy of Effects in Advertising."

${ }^{17}$ Duncan and Caywood, 18.

${ }^{18}$ Schultz, "Integrated Marketing Communications."

${ }^{19}$ Clarke, Caywood, Schultz, and Wang, A Survey of Consumer Goods Manufacturers.

${ }^{20}$ Caywood, Integrated marketing in IBM-Midwest.

${ }^{21}$ Percy, Strategies for Integrating Marketing Communications.

${ }^{22}$ Mulhern, "Integrated marketing communications."

${ }^{23}$ Duncan and Caywood.

${ }^{24}$ Grant, Propaganda.

${ }^{25}$ Marchand, Creating the Corporate Soul; Bird, Jr., Better Living.

${ }^{26}$ RMA POST 108/5, 'Post Office Publicity Committee Minutes of Meetings 1931-33, June 25 1931, Report on Post Office Telephone Publicity Activities.' See also Grant, Propaganda, 110.

${ }^{27}$ Ibid., 86-89.

${ }^{28}$ RMA POST 108/5, 'Post Office Publicity Committee Minutes of Meetings 1931-33, June 25 1931, Report on Activities at Industrial and Trade Exhibitions.' See also 'Report on Post Office Telephone Publicity Activities.'

${ }^{29}$ Ibid., 'Post Office Publicity Committee Minutes of Meetings 1931-33, June 25 1931, Report on Activities of Telephone Development Association.'

${ }^{30}$ Ibid., 'Post Office Publicity Committee Minutes of Meetings 1931-33, June 25 1931.' See also Grant, Propaganda, 100-101. For William Crawford see LeMahieu, A Culture for Democracy, 210-211; Anthony, Public Relations, 37-41 and Schwarzkopf, "Who Said "Americanization?", 52-56.

${ }^{31}$ For Grierson see Aitken, Film and Reform. For Beddington see Heller, "Corporate Brand Building"; LeMahieu, A Culture for Democracy, 267.

${ }^{32}$ Ibid.

${ }^{33}$ Saler, The Avant-Garde in Interwar England.

${ }^{34}$ For the EMB see Constantine, "Bringing the Empire Alive"; LeMahieu, A Culture for Democracy, 166-169.

${ }^{35}$ Ibid., 169; Constantine, "Bringing the Empire Alive," 205-214; Anthony, Public Relations, 29-32.

${ }^{36}$ RMA POST 108/5, 'Post Office Publicity Committee Minutes of Meetings 1931-33, October 10, 1933.'

${ }^{37}$ Ibid., 'Post Office Publicity Committee Minutes of Meetings 1931-33, June 25 1931, Report on Post Office Telephone Publicity Activities.'

${ }^{38}$ For Telephone Week see British Telecom Archives (BTA) POST 33/4856, 'Publicity Telephone Week General Papers.'

${ }^{39}$ RMA POST 108, 'Post Office Publicity Committee Minutes of Meetings 1936-37, Report on "Instruction on Post Office Services in School," May 1 1937.'

${ }^{40}$ Campbell-Smith, 304-314 and Anthony and Mansell, The Projection of Britain. For the GPO's posters see Rennie, GPO Design Posters and for films see British Film Institute and Royal Mail, The GPO Film Unit Collection Volumes One and Two.

${ }^{41}$ See Anthony, "The GPO Film Unit"; Suga, "GPO Films and Modern Design"; Boon, "Old Industry, New Science?" For the development of corporate brands by organisations in Britain in the interwar period see Saler, The Avant Guard in Interwar England and Heller, "Corporate Brand Building."

${ }^{42}$ RMA POST 110/3180-83, 'Outposts of Britain Poster Series'; RMA POST 109/209-212, 'Outposts of Empire Poster Series'; British Film Institute and Royal Mail, The GPO Film Unit Collection Volumes One and Two. ${ }^{43}$ RMA, Stephen Tallents, "Post Office Publicity," The Post Office Green Papers no. 8 (1935). 
${ }^{44}$ Ibid., 10-11.

${ }^{45}$ Ibid., 6, 11.

${ }^{46}$ Ibid., 11. See also RMA POST 108/9, 'Post Office Publicity Committee Minutes of Meetings 1936-37, Report on "Post Early Campaign," July 5 1937.'

${ }^{47}$ Tallents, "Post Office Publicity", 6.

${ }^{48}$ Ibid., 11-22. See also Anthony, Public Relations, 113-119.

${ }^{49}$ For details see BTA POST 33/4856, 'Publicity Telephone Week General Papers.'

${ }^{50}$ RMA POST 108/5-6, 'Post Office Publicity Committee Minutes of Meetings 1933-34.'

${ }^{51}$ For full details of the campaign see RMA POST 108/6, 'Post Office Publicity Committee Minutes of Meetings 1934, October Telephone Campaign Report, October 4, 1934.' BTA POST 33/4856, 'Publicity Telephone Week General Papers, Report on Telephone Week September 18, 1934.' See also BTA POST 33/4856, 'Publicity Telephone Week General Papers, Telephone Week Various T.W. Refs issued, Report on Telephone Week, July 27, 1934.'

52 RMA POST 108/6, 'Post Office Publicity Committee Minutes of Meetings 1934, October Telephone Campaign Report, October 4, 1934.'

53 "Get On The Telephone A National Week." The Times, October 1, 1934, 12; "A Cheerful Start to October." Daily Mail, October 1, 1934, 7; “Shilling 'Phone - 700 Miles Daily Express Has The first Call.” Daily Express, October 1, 1934, 1; "Popularising The Telephone Country-Wide Campaign." Daily Telegraph, October 1, 1934, 17; “'Phone Week Opens." Daily Telegraph, October 2, 1934, 7; "Record Rush to 'Phone Last Night." Daily Express, October 2, 1934, 1; "Success of Telephone Week." The Times, October 12, 1934, 11.

${ }^{54}$ BTA POST 33/4856, 'Publicity Telephone Week General Papers, Report on Telephone Week 18 September, 1934.'

55 Ibid.

${ }^{56}$ For bureaus see BTA POST 33/4856, 'Publicity Telephone Week General Papers, Telephone Week Various T.W. Refs issued, Suggested Display for Telephone Week.'

57 "Success of Telephone Week." The Times, October 12, 1934, 11.

${ }^{58}$ Pathe Gazette, 1934. “Telephone Week Inaugurated.” http://www.britishpathe.com/video/telephone-weekinaugurated/query/telephone+week.

59 "Get On The Telephone A National Week." The Times, October 1. See also RMA POST 108, 'Post Office Publicity Committee Minutes of Meetings 1934, October 4, 1934.'

${ }^{60}$ See, for example, "'Phone Week Opens.” Daily Telegraph, October 2, 1934, 7.

${ }^{61}$ Pathe Gazette, 1934. "Telephone Week Inaugurated."

${ }^{62}$ See reports from post offices in London on results of Telephone Week in BTA POST 33/4856, 'Publicity Telephone Week General Papers, London Telephone Service Reports.'

${ }^{63}$ For a list of businesses involved in Telephone Week see BTA POST 33/4856, 'Publicity Telephone Week General Papers, Telephone Week Various T.W. Refs issued.'

${ }^{64}$ BTA POST 33/4856, 'Publicity Telephone Week General Papers, London Telephone Service Reports, Report of Controller of London Telephone Service, December 10, 1934.'

${ }^{65}$ RMA POST 108/7, 'Post Office Publicity Committee Minutes of Meetings 1934, January 17, 1935.'

${ }^{66}$ BTA POST 33/4856, 'Publicity Telephone Week General Papers, London Telephone Service Reports, Report of Controller of London Telephone Service, December 10, 1934.'

${ }^{67}$ Ibid., 'Telephone Week Reports Scotland.'

${ }^{68}$ For details see RMA POST 108/113, 'Press Notices, Telephone Service to Japan, March 4, 1934,' and RMA POST 108/113, 'Press Notices, Official Opening of the Anglo-Japanese Radiotelephone Service, March 12, 1935.' See also RMA POST 108/7, 'Post Office Publicity Committee Minutes of Meetings 1935, Press Editorial Progress Report, April 29, 1934.'

${ }^{69}$ See "Radio-Telephone to Kenya." The Times, March 7, 1936, 4.

${ }^{70}$ For India see "Hullo India You Can 'Phone Bombay Now." Daily Mail, May 2, 1933, 2; "India On The Ether." Daily Telegraph, May 2, 1933, 10. For newsreel see Pathe Gazette, 1933, "Hullo ... India! Aka Hello India.” http://www.britishpathe.com/video/hullo-india-aka-hello-india/query/india+telephone

${ }^{71}$ See RMA POST 108/113, 'Press Notices, Telephone Service to Japan, March 4, 1934' and RMA POST 108/113, 'Press Notices, Official Opening of the Anglo-Japanese Radiotelephone Service, March 12, 1935.'

72 RMA POST 108/7, 'Post Office Publicity Committee Minutes of Meetings 1935, Press Editorial Progress Report, April 29, 1935.'

${ }^{73}$ RMA POST 108/113, 'Press Notices, Telephone Service to Japan, March 4, 1935' and RMA POST 108/113, 'Press Notices, Official Opening of the Anglo-Japanese Radiotelephone Service, March 12, 1935.'

${ }^{74}$ RMA POST 108/7, 'Post Office Publicity Committee Minutes of Meetings 1935, Press Editorial Progress Report, 29 April, 1935.' 
75 "First 'Phone Call to Tokio." Daily Telegraph, March 13, 1935, 9; "London Rings Up Tokio.” Daily Mail, 13 March, 1935, 18; "They Talked to Tokyo." Daily Express, March 13, 1935, 13; "Radiotelephone Service to the Far East." The Times, March 13, 1935, 9.

${ }^{76}$ Pathe Gazette, 1935, "London Calling Tokyo." http://www.britishpathe.com/video/london-callingtokyo/query/japan+telephone

${ }^{77}$ Ibid.

78 "Radiotelephone Service to the Far East." The Times, March 13, 1935, 9.

79 "First 'Phone Call to Tokio." Daily Telegraph, March 13, 1935, 9, 11.

80 "First Airmail to Australia." Daily Telegraph, December 10, 1934, 5.

${ }^{81}$ RMA POST 108/9, 'Post Office Publicity Committee Minutes of Meetings 1937, Empire Air Mail Scheme, July 5, 1937.' See also RMA POST 108/113, 'Press Notices, Empire Airmail Scheme, May 26, 1937.'

${ }^{82}$ For details see RMA POST/113, 'Press Notices, Official Programme of the Ceremony for Inauguration of Empire Airmail Scheme, June 30, 1937.'

${ }^{83}$ RMA POST/113, 'Press Notices, Broadcast to the Empire by the Postmaster General, June 30, 1937.'

${ }^{84}$ Ibid., 'Press Notices, Official Programme of the Ceremony [for inauguration of Empire Airmail Scheme, June 30, 1937. ' "'All Up' Empire Air Mail." The Times, June 30, 1937, 10; "First 1 1/2 d Air Mail Leaves for South Africa." Daily Mail, June 30, 1937, 6; "King's Letter by Air Mail.” Daily Telegraph, June 30, 1937.

85 “'All Up' Empire Air Mail." The Times, June 30, 1937, 9, 10.

${ }^{86}$ RMA POST 108/9, 'Post Office Publicity Committee Minutes of Meetings 1937, Empire Air Mail Scheme, July $5,1937$.

${ }^{87}$ Ibid.

${ }^{88}$ RMA POST 108/5, 'Post Office Publicity Committee Minutes of Meetings 1931, December 8, 1931.'

${ }^{89}$ Ibid., 'Post Office Publicity Committee Minutes of Meetings 1932, July 4, 1932.'

${ }^{90}$ Ibid., 'Post Office Publicity Committee Minutes of Meetings 1931, July 12, 1933.'

${ }^{91}$ RMA POST 108/9, 'Post Office Publicity Committee Minutes of Meetings 1937, May 6, 1937.'

${ }^{92}$ RMA POST 108/5, 'Post Office Publicity Committee Minutes of Meetings 1933, November 23, 1933.'

${ }^{93}$ Campbell-Smith, 310.

${ }^{94}$ RMA POST 108/9, 'Post Office Publicity Committee Minutes of Meetings 1936-1937, Telephone Progress Report, April 23, 1936.'

${ }^{95}$ Ibid., 320.

96 'Post Office Publicity Committee Minutes of Meetings 1936-1937, Telegraphs: Progress Report, 17 February, 1936.' For Savings Bank see RMA POST 108/11, 'Post Office Publicity Committee Minutes of Meetings 1938, October 13, 1938.'

${ }^{97}$ Grant, 82.

98 "Business-Like Government." The Times, December 18, 1934, 12.

${ }^{99}$ See letter from the Whitby Gazette of October 3, 1934 in BTA POST 33/4856, 'Publicity Telephone Week General Papers, North Eastern District.'

${ }^{100}$ Schwarzkopf, "Who Said "Americanization?"

\section{References}

Aitken, I. Film and Reform: John Grierson and the Documentary Film Movement (London: Routledge, 1990).

Anthony, S. "The GPO Film Unit and 'Britishness' in the 1930s." In The Projection of Britain A History of the GPO Film Unit, edited by S. Anthony and J. G. Mansell, 10-17. Basingstoke: Palgrave Macmillan, 2011.

Anthony, S. and J. G. Mansell, eds. The Projection of Britain A History of the GPO Film Unit. Basingstoke: Palgrave Macmillan, 2011.

Anthony, S. Public Relations and the Making of Modern Britain: Stephen Tallents and the Birth of a Progressive Media Profession. Manchester: Manchester University Press, 2012.

Anthony, S. and J. G. Mansell. "Introduction: The Documentary Film Movement and the Spaces of British Identity." Twentieth Century Business History 23, no. 1 (2012): 1-11. 
Balmer, J. "Corporate marketing: Integrating corporate identity, corporate branding, corporate communications, corporate image and corporate reputation." European Journal of Marketing 40, nos. 7/8 (2006): 730-741.

Barry, T.E. and D.J. Howard. "A Review and Critique of the Hierarchy of Effects in Advertising." International Journal of Advertising 9, no. 2 (1990): 121-135.

Bird, Jr. W.L. Better Living Advertising, Media and the New Vocabulary of Business Leadership, 19351955. Evanston, IL: Northwestern University Press, 1999.

Boon, T. "Old Industry, New Science? The GPO Film Unit between Palaeotechnology and Neotechnology." In The Projection of Britain A History of the GPO Film Unit, edited by S. Anthony and J. G. Mansell, 28-35. Basingstoke: Palgrave Macmillan, 2011.

British Film Institute and Royal Mail. The GPO Film Unit Collection Volumes One and Two. London: British Film Institute and Royal Mail, 2008/2009. DVD.

Campbell-Smith, D. Masters of the Post The Authorized History of the Royal Mail. London: Penguin Books, 2011.

Caywood, C.L. Integrated marketing in IBM-Midwest: The distribution market. Evanston, IL: Northwestern University Press, 1991.

Caywood, C.L., D. E. Schultz, and P. Wang. A Survey of Consumer Goods Manufacturers. New York: American Association of Advertising Agencies, 1991.

Church, R. "Advertising consumer goods in nineteenth century Britain: reinterpretations." Economic History Review LIII, no. 3 (2000), 621-645.

Constantine, S. "Bringing the Empire Alive: The Empire Marketing Board and Imperial Propaganda, 1926-1933." In Imperialism and Popular Culture, edited by John Mackenzie, 192-231. Manchester: Manchester University Press, 1986.

Duncan, T. and C. Caywood, "The Concept, Process, and Evolution of Integrated Marketing Communication." In Integrated Communication: Synergy of Persuasive Voices, edited by E. Thorson and J. Moore, 13-34. Mahwah, New Jersey: Lawrence Erlbaum Associates, 1996.

Grant, M. Propaganda and the Role of the State in Inter-War Britain. Oxford: Clarendon Press, 1994.

Heller, M. "Corporate Brand Building: Shell-Mex Ltd. in the Interwar Period" in Trademarks, Brands and Competitveness, edited by Teresa da Silva Lopes and Paul Duguid, 194-214. London: Routledge, 2010.

L'Etang, J. Public Relations in Britain A History of Professional Practice in the $20^{\text {th }}$ Century. London: Routledge, 2013.

LeMahieu, D.L. A Culture for Democracy Mass Communication and the Cultivated Mind in Britain Between the Wars. Oxford: Clarendon Press, 1988.

Marchand, R.Creating the Corporate Soul The Rise of Public Relations and Corporate Imagery in American Big Business. Berkley and Los Angeles, California: University of California Press, 1998. 
Mulhern, F. "Integrated marketing communications: From media channels to digital connectivity." Journal of Marketing Communications 15 no. 2-3 (2009): 85-101.

Percy, L. Strategies for Integrating Marketing Communications. Chicago: NTC Publishing Group, 1997.

Rennie, P. GPO Design Posters. Woodbridge, Suffolk: Antique Collectors' Club, 2011.

Saler, M.T. The Avant-Garde in Interwar England Medieval Modernism and the London Underground. Oxford, Oxford University Press, 1999.

Schultz, D.E. "Integrated Marketing Communications." Journal of Promotion Management 1, no. 1 (1991): 99-104.

Schwarzkopf, S. "Who Said "Americanization?" The Case of Twentieth-Century Advertising and Mass-Marketing from a British Perspective." In Decentering America, edited by Jessica C.E. GienowHecht, 23-72. New York, Oxford: Berghahn, 2007.

Suga, Y. "GPO Films and Modern Design." In The Projection of Britain A History of the GPO Film Unit, edited by S. Anthony and J. G. Mansell, 18-27. Basingstoke: Palgrave Macmillan, 2011. 